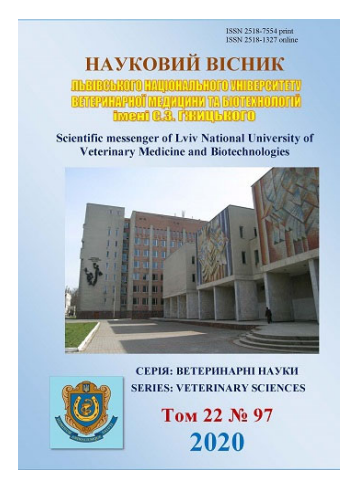

\section{Науковий вісник Дьвівського національного університету ветеринарної медицини та біотехнологій імені С.3. Гжицького. Серія: Ветеринарні науки}

\author{
Scientific Messenger of Lviv National University \\ of Veterinary Medicine and Biotechnologies. \\ Series: Veterinary sciences
}

doi: $10.32718 /$ nvlvet9721

https://nvlvet.com.ua/index.php/journal

UDC 636.09:612.017:615.218

\title{
Investigation of the irritant effects and allergenic properties of the Iron(IV) clathrochelate complexes
}

\author{
V. B. Dukhnitsky ${ }^{1}$, I. M. Derkach ${ }^{1}$, S. S. Derkach ${ }^{1}$, I. O. Fritsky², M. O. Plutenko ${ }^{2}$, V. M. Lozovy ${ }^{1}$ \\ ${ }^{1}$ National University of Life and Environmental Sciences of Ukraine, Kyiv, Ukraine \\ ${ }^{2}$ Taras Shevchenko National University of Kyiv, Kyiv, Ukraine
}

Article info

Received 11.02.2020 Received in revised form 12.03.2020 Accepted 13.03.2020

National University of Life and Environmental Sciences of

Ukraine, Heroyiv Oborony Str., 15 , Kyiv, 03041, Ukraine. Tel.: +38-066-772-41-94 E-mail:irina1215@ukr.net

Taras Shevchenko National University of Kyiv, Volodymyrska Str., 64 Kyiv, 01601, Ukraine. Tel.: +38-097-060-82-98. E-mail:plutenkom@gmail.com

Dukhnitsky, V. B., Derkach, I. M., Derkach, S. S., Fritsky, I. O., Plutenko, M. O., \& Lozovy, V. M. (2020). Investigation of the irritant effects and allergenic properties of the Iron(IV) clathrochelate complexes. Scientific Messenger of Lviv National University of Veterinary Medicine and Biotechnologies. Series: Veterinary sciences, 22(97), 130-135. doi: 10.32718/nvlvet9721

During the preclinical studies of new drugs, the study of the degree of manifestation of their irritant and allergenic effects affects subsequent clinical studies, for example the routes of administration, the need to add excipients to reduce irritation. The article presents the results of studies of the irritant effects and allergenic properties of the Iron in rare unconventional valence - IV. The irritant effect of the Iron(IV) clathrochelate complexes on the skin was studied comprehensively. 20 rabbits were divided into 4 groups (control and three experimental), 5 animals each. The ointment on the vaseline and aqueous solution of the Iron(IV) clathrochelate complexes was applied to the skin of rabbits of the experimental groups. Also this solution was introduced subcutaneously. The investigated dosage forms were used at a dose of $1 \mathrm{ml} / \mathrm{kg}$ body weight (based on the active ingredient $500 \mathrm{mg} / \mathrm{kg}$ body weight of the laboratory animal). The results of the studies showed that of the Iron(IV) clathrochelate complexes has no irritant properties when used externally and is characterized by a lack of local reaction by subcutaneous injection. Determination of allergenic properties was performed by detecting itching and swelling in the guinea pigs in animals which were sensitized with this substance. In addition, in order to assess the severity of the inflammatory reaction, the skin temperature was determined before the experiment and on the 20th day of the experiment, and the skin fold thickness was measured using a caliper. The results of the studies showed that there is no allergic action of the Iron(IV) clathrochelate complexes. The results of the ophthalmic test on laboratory animals confirmed the data obtained.Therefore, comprehensive studies of the irritant and allergenic effects of the Iron(IV) clathrochelate complexes were performed for the first time. The Iron(IV) clathrochelate complexes in the form of ointment and solution does not irritate the skin and mucous membranes and has no allergenic properties to the body of the laboratory animals.

Key words: hexahydrazide clathrochelate, toxicology, rabbits, guinea pigs.

\section{Дослідження подразнювальної дії та алергенних властивостей клатрохелату Феруму(IV)}

\author{
В. Б. Духницький ${ }^{1}$, I. М. Деркач ${ }^{1}$, С. С. Деркач ${ }^{1}$, I. О. Фрицький ${ }^{2}$, М. О. Плутенко을 В. М. Лозовий ${ }^{1}$
}

${ }^{1}$ Національний університет біоресурсів і природокористування Украӥни, м. Київ, Украӥна

${ }^{2}$ Київський національний університет імені Тараса Шевченка, м. Київ, Украӥна

За проведення доклінічних досліджень нових лікарських засобів вивчення ступеня прояву їх подразнювальної та алергенної дій впливає на хід наступних клінічних досліджень, наприклад, на способи введення, необхідність додавання допоміжних речовин для зниження подразнювальної дї тощу. У статті представлені результати досліджень подразнювальної дї та алергенних властивостей Феруму у рідкісній нетрадиційній валентності - IV. Подразнювальну дію клатрохелату Феруму(IV) на шкіру вивчали на 
20 кролях, яких було розподілено на 4 групи (контрольну та три дослідні), по 5 тварин у кожній. На шкіру кролів ІІ дослідної групи наносили мазь клатрохелату Феруму(IV) на вазеліні; на шкіру кролів III дослідної групи - водний розчин досліджуваної речовини; кролям IV дослідної групи підшкірно вводили водний розчин клатрохелату Феруму(IV). Досліджувані лікарські форми застосовували у дозі 1 мл/кг маси тіла (з розрахунку діючої речовини 500 мг/кг маси тіла тварини). Результати досліджень засвідчили, щзо клатрохелат Феруму(IV) не володіє подразнювальними властивостями за зовнішнього застосування та характеризується відсутністю місиевої реакиї за підшкірної ін'єкиії. Визначення алергенних властивостей виконували шляхом виявлення свербежу та набряку у сенсибілізованих иією речовиною морських свинках. Результати досліджень засвідчили відсутність алергенної дії клатрохелату Феруму(IV). Результати проведення офтальмопроби на лабораторних тваринах підтвердили отримані дані. Отэже, вперше виконано комплексні дослідження подразнювальної та алергенної дї клатрохелату Феруму(IV). Клатрохелат Феруму(IV) у формі мазі та розчину не діє подразнювально на шкіру і слизові оболонки та не проявляє алергенних властивостей на організм лабораторних тварин.

Ключові слова: гексагідразидний клатрохелат, токсикологія, кролі, морські свинки.

\section{Вступ}

Аліментарна анемія є клініко-гематологічним синдромом, який зумовлений порушенням синтезу гемоглобіну, зменшенням кількості еритроцитів у крові, що $є$ наслідком дефіциту в організмі незамінних факторів мінерально-вітамінного живлення, насамперед Феруму (Evans \& Abraham, 1973; Bonkovsky \& Herbert, 1991; Walter et al., 1997; Killip \& Bennett, 2008; Ganz, 2013). Дану патологію, яка завдає значних економічних збитків особливо свинарським господарствам, реєструють сьогодні у всьому світі. Тож питання удосконалення превентивних заходів щодо неї не втрачає актуальності (Karput' \& Nikoladze, 2003; Batrakov et al., 2005; Jiefen et al., 2017; Kim et al., 2018).

Нині для лікування поросят за однієї з найбільш поширених неінфекційних патологій - ферумдефіцитної анемії на фармацевтичному ринку України пропонується 14 ферумдекстранових препаратів (зареєстрованих станом на 1.03.2020). Українські та закордонні виробники випускають їх у формі розчинів для внутрішньом'язових ін'єкцій. Діючою речовиною цих препаратів є комплекс Феруму у валентностях II або III $з$ декстраном, який у деяких із них доповнюється іншими мікроелементами чи вітамінами (Derkach, 2017).

Нами раніше повідомлялося про результати доклінічних досліжень нової органічної сполуки Феруму клатрохелату Феруму у рідкісній валентності IV, синтез якої вперше описаний Tomyn et al., (2017). Дана речовина може бути запропонована у складі ефективного протианемічного засобу для поросят (Dukhnitsky et al., 2018; 2019).

Відповідно до постанови Департаменту ветеринарної медицини "Токсикологічний контроль нових засобів захисту тварин”, затверджених Головним управлінням ветеринарної медицини Мінсільгосппроду України від 16 грудня 1996 р., кожний новий препарат, що рекомендується для лікування тварин, повинен відповідати таким вимогам: проявляти вищу терапевтичну ефективність, порівняно з препаратоманалогом; бути нетоксичним для тварин, яким його застосовують; не повинен впливати на санітарну якість та поживну цінність тваринницької продукції; не спричиняти шкоди для довкілля у процесі виробництва та застосування.
До вивчення загальнотоксичної дії нових ветеринарних препаратів відносять дослідження гострої (підгострої) та хронічної токсичності, кумулятивних властивостей, побічних дій і віддалених наслідків. Такі токсикологічні дослідження є обов'язковими для всіх лікарських засобів.

У цьому контексті нові речовини підлягають також спеціальному вивченню $з$ метою визначення ступеня небезпеки отруєнь за потрапляння на шкіру. Швидкість проникнення в організм через шкіру залежить від хімічної структури та фізико-хімічних властивостей (від розчинності у воді та органічних розчинниках) (Kotsiumbas, 2006).

Для визначення проникнення речовин через шкіру $\epsilon$ методи, які поділяють на три групи: кількісне визначення речовин або їх метаболітів в організмі, кількісне визначення речовин у місці нанесення, оцінка загальної реакції організму на дію препарату. Вони мають ряд недоліків, серед яких необхідність враховувати нерівномірний розподіл препарату в різних органах, ймовірність тривалого затримання речовин в організмі, інструментальні методи визначення речовин та їх метаболітів тощо.

\section{Матеріал і методи досліджень}

Дослідження подразнювальної та алергенної дії клатрохелату Феруму(IV) $\mathrm{Na}_{2}[\mathrm{Fe}(\mathrm{L}-6 \mathrm{H})] \cdot 2 \mathrm{H}_{2} \mathrm{O}$ (L макробіциклічний гексагідразидний ліганд) проводили на лабораторних тваринах (кролях та морських свинках), яких утримували в стаціонарі кафедри акушерства, гінекології та біотехнології відтворення тварин факультету ветеринарної медицини НУБіП України. У приміщеннях проводився контроль сталої температури повітря та вологості. Годівля тварин передбачала стандартний раціон 3 постійним доступом до води.

Перед початком досліду тварин утримували в адаптаційному періоді 10 діб. Відхилень у поведінкових реакціях кролів та морських свинок як у дослідній, так і контрольній групах не спостерігали. Усі дослідження проводили з урахуванням "Загальних етичних принципів експериментів на тваринах" (Україна, 2001) та згідно з положеннями Свропейської конвенції щодо захисту хребетних тварин (Stratsburg: Counsil of Europe 18.03.1986).

Подразнювальну дію клатрохелату Феруму(IV) на шкіру вивчали на 20 кролях масою тіла 1800-2000 г, 
шкіра яких не мала ознак ураження. Тварин за принципом аналогів було розподілено на 4 групи (I контрольну та три дослідні) по 5 тварин у кожній.

У тварин проводили відповідну підготовку шкіри. За добу до проведення досліду на ділянці спини кролів здійснювали депіляцію шкіри на площі $6 \mathrm{~cm}^{2}$ i знежирювали їі етиловим спиртом.

На шкіру кролів II дослідної групи наносили мазь клатрохелату Феруму(IV) на вазеліні (рис. 1); на шкі- ру кролів III дослідної групи за допомогою марлевого тампону наносили водний розчин досліджуваної речовини (рис. 2), кролям IV дослідної групи підшкірно вводили водний розчин клатрохелату Феруму(IV) (рис. 3). Досліджувані лікарські форми застосовували у дозі 1 мл/кг маси тіла (з розрахунку діючої речовини 500 мг/кг маси тіла). Тваринам I контрольної групи за допомогою марлевого тампону наносили дистильовану воду.

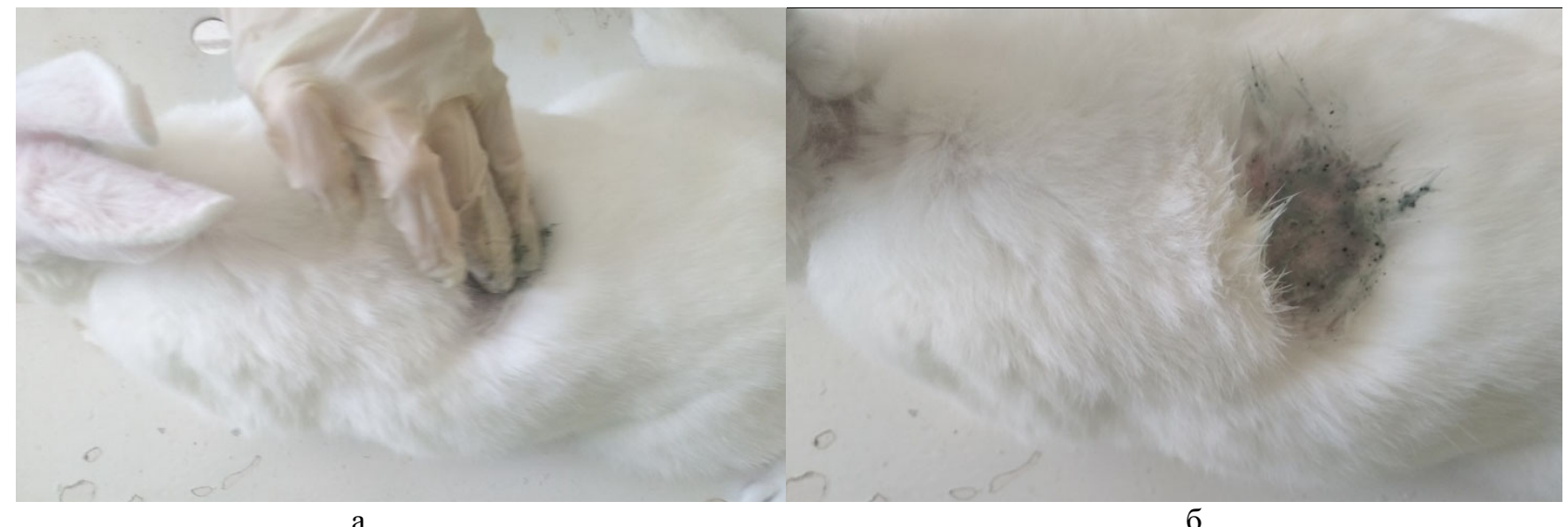

Рис. 1. Дослідження подразнювальної дії клатрохелату Феруму(IV) на шкірі кролів II дослідної групи

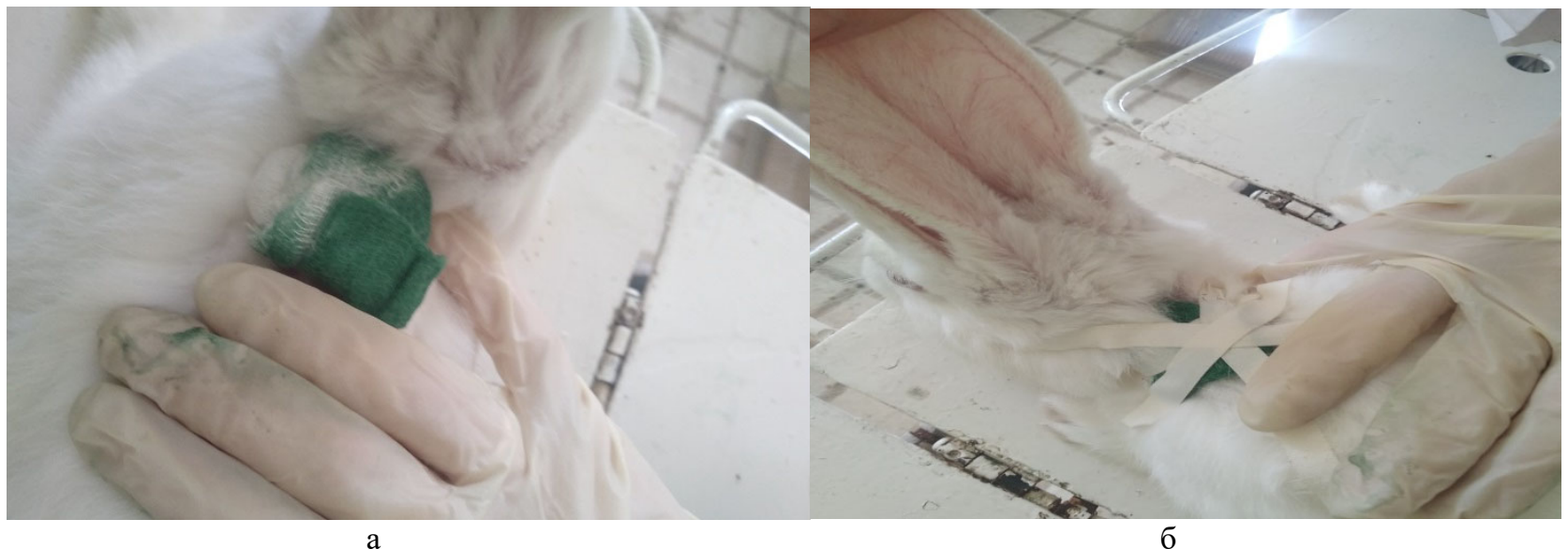

Рис. 2. Дослідження подразнювальної дії клатрохелату Феруму(IV) на шкірі кролів III дослідної групи.

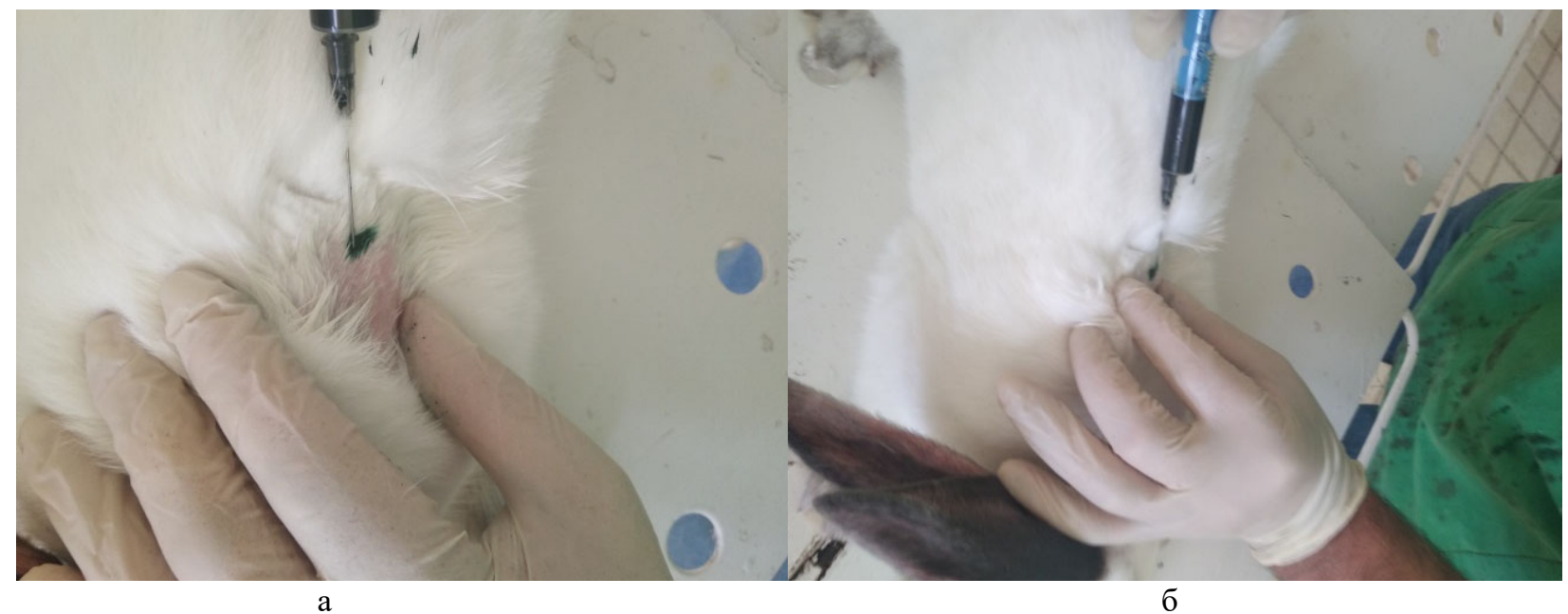

Рис. 3. Дослідження подразнювальної дії клатрохелату Феруму(IV) за підшкірної ін'єкції кролям IV дослідної групи 
Через 6, 24 і 48 год після застосування лікарських форм клатрохелату Феруму(IV) визначали їх подразнювальну дію за наявністю (відсутністю) гіперемії і набряку шкіри та за товщиною складки шкіри, яку вимірювали мікрометром. Больову реакцію тварин визначали пальпацією місць аплікації/ін'єкції досліджуваної речовини. За тваринами здійснювали спостереження впродовж двох тижнів.

Подразнювальну дію клатрохелату Феруму(IV) на слизову оболонку ока досліджували на 5 кролях. У кон'юнктивальний мішок лівого ока тварин із піпетки закапували по 2 краплі водного розчину клатрохелату Феруму(IV) тіла (з розрахунку діючої речовини 500 мг/кг маси тіла тварини). Для контролю в праве око тваринам закапували по 2 краплі ізотонічного розчину натрію хлориду. Тварин фіксували, відтягували кут кон'юнктивального мішка і протягом 1 хв пальцем перетискали слізно-носовий канал. Подразнювальну дію клатрохелату Феруму(IV) визначали за наявністю/відсутністю гіперемії кон'юнктиви, ін'єкцією кровоносних судин, станом склери, рогівки, повік.

Досліди з вивчення алергенних властивостей клатрохелату Феруму(IV) проводили на 10 морських свинках масою 500-600 г, яких, в свою чергу, було розподілено на дві групи: I контрольну та II дослідну, по 5 тварин у кожній. У зв'язку з відсутністю подразнювальної дії досліджуваної речовини визначення алергенних властивостей виконували шляхом виявлення свербежу та набряку у сенсибілізованих цією речовиною тварин.

Морським свинкам II дослідної групи $(\mathrm{n}=5)$ дворазово 3 інтервалом 12 год вводили у кон'юнктивальний мішок по 0,05 мл водного розчину клатрохелату Феруму(IV) (з розрахунку діючої речовини 500 мг/кг маси тіла тварини). За таких же умов тваринам I контрольної групи $(\mathrm{n}=5)$ вводили стерильний ізотонічний розчин Натрію хлориду.

Для одержання контактної сенсибілізації на депі-

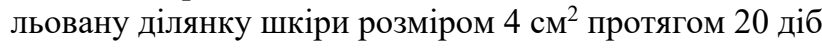
наносили мазь тваринам дослідної групи та основу мазі вазелін тваринам контрольної групи. Стан шкіри тварин оцінювали в балах за вираженістю гіперемії через 20 діб після нанесення препарату та порівнюва- ли 3 інтактною ділянкою шкіри. Крім того, з метою оцінки вираженості запальної реакції, до початку та на 20 добу експерименту визначали температуру шкіри, а за допомогою штангенциркуля вимірювали товщину складки шкіри.

Експерименти на тваринах були проведені 3 дотриманням вимог «Загальних етичних принципів експериментів над тваринами», схвалених Національним конгресом з біоетики і узгоджених 3 положеннями “Свропейської конвенції щодо захисту хребетних тварин, яких використовують в експериментах та інших наукових цілях" (Страсбург, 1986) та Закону України "Про захист тварин від жорстокого поводження” (Відомості ВР, 2010).

\section{Результати та їх обговорення}

Токсичність клатрохелату Феруму(IV) вивчали за показниками подразнювальної дії (за шкірною та кон'юнктивальною пробами), алергенної дії (метод аплікації на шкіру).

Протягом перших годин тварини проявляли неспокій, що можна розглядати як стресову відповідь на втручання. Через 24 год стан тварин нормалізувався, відновився апетит та рухова активність. Загибелі тварин не спостерігали.

Встановлено, що за показниками гіперемії і набряку шкіри та товщини шкірної складки клатрохелат Феруму(IV) за аплікацій на шкіру та підшкірної ін'єкції не спричиняв у кролів місцевої подразнювальної дії (табл. 1-2).

\section{Таблиця 1}

Характеристика подразнювальної дії клатрохелату Феруму(IV) на шкірі кролів $(\mathrm{M} \pm \mathrm{m} ; \mathrm{n}=5)$

\begin{tabular}{ccc}
\hline \multirow{2}{*}{ Група тварин } & \multicolumn{2}{c}{ Середній бал вираженості } \\
\cline { 2 - 3 } & Набряк & Еритема \\
\hline I Контрольна & 0 & 0 \\
II Дослідна & 0 & 0 \\
III Дослідна & 0 & 0 \\
IV Дослідна & 0 & 0 \\
\hline
\end{tabular}

Таблиця 2

Товщина складки шкіри кролів після застосування клатрохелату Феруму(IV) (M \pm m; n = 5)

\begin{tabular}{lccc}
\hline \multirow{2}{*}{ Група тварин } & \multicolumn{3}{c}{ Товщина складки шкіри, мм } \\
\cline { 2 - 4 } & 6 год & 24 год & 48 год \\
\hline I Контрольна & $2,04 \pm 0,01$ & $2,05 \pm 0,03$ & $2,08 \pm 0,02$ \\
II Дослідна & $2,06 \pm 0,27$ & $2,06 \pm 0,01$ & $2,07 \pm 0,01$ \\
III Дослідна & $2,05 \pm 0,32$ & $2,06 \pm 0,01$ & $2,06 \pm 0,03$ \\
IV Дослідна & $2,06 \pm 0,01$ & $2,07 \pm 0,01$ & $2,07 \pm 0,02$ \\
\hline
\end{tabular}

Результати досліджень, представлені в таблиці, підтверджують, що клатрохелат Феруму(IV) не володіє подразнювальними властивостями за зовнішнього застосування та характеризується відсутністю місцевої реакції за підшкірної ін'єкції.
Не встановлено реакції кон'юнктиви кролів на дію розчину клатрохелату Феруму(IV), через 30 хв, 1, 3, 6, 12, 24 і 48 год після інстиляції препарату (табл. 3). 


\section{Таблиця 3}

Вплив клатрохелату Феруму(IV) на кон'юнктиви, рогівки та повіки очей кролів $(\mathrm{M} \pm \mathrm{m} ; \mathrm{n}=5)$

\begin{tabular}{ccc}
\hline Час досліду & Оцінка в балах & $\begin{array}{c}\text { Подразнювальний } \\
\text { ефект }\end{array}$ \\
\hline До введення & 0 & Відсутній \\
Через 30 хв & 0 & Відсутній \\
Через 1 год & 0 & Відсутній \\
Через 3 год & 0 & Відсутній \\
Через 6 год & 0 & Відсутній \\
Через 12 год & 0 & Відсутній \\
Через 24 год & 0 & Відсутній \\
Через 48 год & 0 & Відсутній \\
\hline
\end{tabular}

Отже, клатрохелат Феруму(IV) не володіє подразнювальними властивостями на шкірі та кон'юнктиви кролів.

У морських свинок дослідної групи, яким упродовж 20 діб наносили на шкіру клатрохелат Феруму (IV) у формі мазі на вазеліні, не спостерігали свербежу, підвищення місцевої температури та набряку шкіри, що засвідчує відсутність алергічної реакції. Реакцію також не спостерігали у морських свинок контрольної групи, яким наносили мазеву основу вазелін (табл. 4).

\section{Таблиця 4}

Характеристика алергенних властивостей клатрохелату Феруму(IV) на організм сенсибілізованих морських свинок $(\mathrm{M} \pm \mathrm{m} ; \mathrm{n}=5)$

\begin{tabular}{lccc}
\hline \multirow{2}{*}{ Група тварин } & \multicolumn{3}{c}{ Середній бал вираженості } \\
\cline { 2 - 4 } & Свербіж & Набряк & Гіперемія \\
\hline I Контрольна & 0 & 0 & 0 \\
II Дослідна & 0 & 0 & 0 \\
\hline
\end{tabular}

Результати досліджень, представлені в таблиці 4, підтверджують, що клатрохелат Феруму(IV) не володіє алергенними властивостями. Дослід також показав відсутність реакції кон'юнктиви сенсибілізованих i інтактних морських свинок через 1 і 12 годин на інстиляцію препарату.

\section{Висновки}

Клатрохелат Феруму(IV) у формі мазі та розчину не діє подразнювально на шкіру і слизові оболонки та не проявляє алергенних властивостей на організм тварин після багаторазової аплікації.

\section{References}

Batrakov, A. Ja., Travkin, O. V., \& Jakovleva, E. V. (2005). Profilaktika alimentarnoj anemii u porosjat. Veterinarija, 12, 44-45 (in Russian).

Bonkovsky, S., \& Herbert, L. (1991). Iron and the Liver. The American journal of the medical sciences, 301(1), 32-43. doi: 10.1097/00000441-199101000-00006.

Commission of the European Communities: Council Directive of 18 December 1986 on the Lows, regulat- ing the Application of Principles of Good Laboratory Practice and the Verification of Their Applications for Tests on Chemical Substances (87/18/EEC) (1991). The Rules Governing Medicinal Products in the European Community, 1, 145-146.

Derkach, I. (2017). Suchasni tendencii na vitchyznjanomu rynku ferumvmisnyh preparativ dlja tvaryn [Modern trends of the Ukrainian market of ferumcontaining products for animals]. Naukovyj visnyk Lvivskogo nacionalnogo universytetu veterynarnoi medycyny ta biotehnologij imeni S. Z. Gzhyckogo, 19(78), 23-25. doi: 10.15421/nvlvet7805 (in Ukrainian).

Dukhnitsky, V. B., Derkach, I. M., Derkach, S. S., Plutenko, M. O. \& Fritsky, I. O. (2019). Influence of iron (IV) clathrochelate complex on quail blood parameters and weight characteristics. Ukrainian Journal of Ecology, 9(3), 126-131. doi: 10.15421/2019_719.

Dukhnitsky, V. B., Derkach, I. M., Plutenko, M. O., Fritsky, I. O., \& Derkach, S. S. (2018). Vyznachennja parametriv gostroi toksychnosti ferumu (IV) na bilyh myshah [Determination of the accumulative toxicity parameters of iron (IV) on white mice]. Ukrainian Journal of Ecology, 8 (2), 308-312. doi: 10.15421/2018_343 (in Ukrainian).

Dukhnitsky, V. B., Derkach, I. M., Plutenko, M. O., Fritsky, I. O., \& Derkach, S. S. (2019). Cumulative properties of Iron(IV) clathrochelate in rats [Kumuliatyvni vlastvosti klatrokhelatu Ferumu (IV) dlia bilykh shchuriv]. Visnyk PDAA, 2, 238-246 (in Ukrainian).

Dukhnitsky, V. B., Kalachniuk, L. H., Derkach, I. M., Derkach, S. S., Plutenko, M. O. \& Fritsky, I. O. (2020). Iron(IV) hexahydrazide clathrochelate complexes: the chronic toxicity study. Ukrainian Journal of Ecology, 9(3), 18-23. doi: 10.15421/2020_3.

Dukhnitsky, V., Derkach, I., Derkach, S., Fritsky, I., \& Plutenko, M. (2019). Chronic toxicity of the Iron (IV) clathrochelate complexes for white rats [Khronichna toksychnist klatrokhelatu Ferumu (IV) dlia bilykh shchuriv]. Scientific Messenger of LNU of Veterinary Medicine and Biotechnologies. Series: Veterinary Sciences, 21(95), 15-21. doi: 10.32718/nvlvet9503 (in Ukrainian).

Dukhnitsky, V., Derkach, I., Plutenko, M., Fritsky, I., \& Derkach, S. (2019). Acute toxicity of the iron clathrochelate complexes. Regulatory Mechanisms in Biosystems, 10(3), 276-279. doi: 10.15421/021942.

Evans, J. L., \& Abraham, P. A. (1973). Anemia, Iron Storage and Ceruloplasmin in Copper Nutrition in the Growing Rat. The Journal of Nutrition, 103(2, 1), 196-201. doi: 10.1093/jn/103.2.196.

Ganz, T. (2013). Systemic iron homeostasis. Physiological Reviews, 93(4), 1721-1741. doi: 10.1152/physrev.00008.

Jiefen, C., Yinping, L., Peng, Y., Qiping, Zh., Jingfeng, W., Yongzhou, Ch., \& Peng, W. (2017). A novel low molecular weight Enteromorpha polysaccharide-iron (III) complex and its effect on rats with iron 
deficiency anemia (IDA). International journal of biological macromolecules, 108, 412-418. doi: 10.1016/j.ijbiomac.2017.12.033.

Karput', I. M., \& Nikoladze, M. G. (2003). Diagnostika i profilaktika alimentarnoj anemii porosjat. Veterinarija, 4, 34-37 (in Russian).

Killip, S., \& Bennett, M. (2008). Iron Deficiency Anemia. American Family Physician., 78(8), 671-678. https://www.aafp.org/afp/2013/0115/p98.html.

Kim, J. C., Wilcock, P., \& Bedford, M. R. (2018). Iron status of piglets and impact of phytase superdosing on iron physiology: A review. Animal Feed Science and Technology, 235, 8-14.
Kocjumbas, I. Ja. (2006). Doklinichni doslidzhennja veterynarnyh likars'kyh zasobiv. L'viv. Triada pljus (in Ukrainian).

Toksykolohichnyi kontrol novykh zasobiv zakhystu tvaryn (Metodychni rekomendatsii) (1996). Holovnym upravlinniam veterynarnoi medytsyny Min. Silhospprodu Ukrainy. Kyiv, 33 (in Ukrainian).

Tomyn, S., Shylin, S. I., Bykov, D., Ksenofontov, V., Gumienna-Kontecka, E., Bon, V., \& Fritsky, I. O. (2017). Indefinitely stable iron (IV) cage complexes formed in water by air oxidation. Nature Communications, $8,1-8$.

Walter, T., Olivares, M., Pizarro, F., \& Muñoz, C. (1997). Iron, Anemia, and Infection. Nutrition Reviews, 55(4), 111-124. doi: 10.1111/j.1753-4887.1997.tb06462.x. 